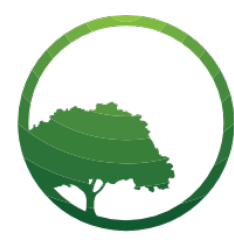

Business \& Social Science IJRBS

\section{Research in Business and Social Science}

IJRBS Vol 6 No 6, ISSN: 2147-4478

Contents available at www.ssbfnet.com/ojs

Doi: $10.20525 i j r b s . v 6 i 6.732$

\title{
Self Efficacy on Work at Government Agencies in Bandung, Indonesia
}

\section{Senen Machmud}

School of Economic Pasundan, Bandung, Indonesia, JL. Turangga No. 37 - 41, Bandung, Indonesia. 40263 Tel 622-7303249, 622-7302537, 622-7302491, Fax 622-7309128

\begin{abstract}
This study aims to determine the effect of self-efficacy towards work perception and job satisfaction. The population of this study is the employees of government agencies in Bandung, Indonesia. The total samples are 117 employees with purposive sampling technique. This study uses Partial Least Square-Structural Equation Modeling (SEM) for analyzing the data. The results showed that selfefficacy significantly influences the work perception and job satisfaction. Moreover, it is found that work perception has a significant effect on job satisfaction. It shows that the level of self-efficacy can increase the work perception and job satisfaction. It indicates that the high level of self-efficacy will be a positive influence on the behavior of employees in conducting their duties so that it can increase their job satisfaction.
\end{abstract}

Key words: Self Efficacy, Work Perception, Job Satisfaction

JEL classification: D91, D23, M12

\section{Introduction}

According to Newbert (2007), Resource-based view (RBV) of the firm has been considered as one of the fastest growing methods in the current strategic management field. Wernerfelt (1984) argues that organizational success is determined by internal resources and the basis of the heterogeneity concept of valuable resources (Jarvenpaa and Leidner, 1998; Wagner, 2006; Machmud and Sidharta, 2016; Sidharta and Affandi, 2016). RBV shows that aligning skill, motivation, and the other factors with the organizational system, structure, and processes that achieve capabilities at an organizational level by focusing on more efficient resources can acquire organizational success (Prahalad and Hamel, 1990; Barney, et al, 2001). Moreover, the Knowledge-Based View (KBV) originated from the importance of human capital in producing good performance (Becker, 1964; Schultz, 1961).

The role of human resources is important in generating good performance, which requires the continuous 


\section{S. Machmud / International Journal of Research in Business and Social Science,}

Vol 6 No 6, 2017 ISSN: 2147-4486

development to achieve organizational goals. Within the context of public services, the role of HR is the front lines that are directly related to the society. Thus, there is a need of increasing human resources in the government in order to provide the best service for the society. Nowadays, the good government is a real demand for the government. Hence, the need for increasing the capability of human capital so that the effectiveness of government organizations can be optimal.

In general, organizational behavior is an approach that is used in assessing the effectiveness of an organization (Luthans, 2006). Gibson et al. (2010) explain that individual behavior is essentially based on the psychic processes at the individual or organism in a given environment. In this case, the behavior of individuals in assessing the work environment is important in organizational behavior (Edwards and Cooper, 1990). The condition was created from the result of interaction between members of the organization with organizational elements. It means, the members of the organization determine and confirm the existence through a process of interaction between members of the organization and organizational elements. Job satisfaction is the embodiment of individual behavior in organizations which is determined by several factors (Lankau and Scandura, 2002). In this case, the high and low job satisfaction depend on how big these factors create the pressure on employee behavior (Newstroom and Davis, 2002). Robbins and Judge (2006) state that job satisfaction is the general attitude of employees towards their job. It indicates that the perception of employees' job satisfaction depends on how capable they are in completing their job.

Self-efficacy is an individual's perception regarding on his or her ability to successfully complete a given task (Wood and Bandura, 1989). This is important for the employees because they must be confident in their abilities to perform different and unanticipated tasks in uncertain situations; and self-perceived competence is positively related to the job satisfaction (Judge et al. 2003) and performance (Baum and Locke, 2004). Furthermore, self-efficacy has a significant impact on performance in various tasks and it is related to the job performance (Hmieleski and Baron, 2008). It supports an argument that performance is strongly influenced by a person's self-efficacy (Chandler, 2008) and generalized self-efficacy as having a positive impact on the job satisfaction and job performance (Jex and Bliese, 1999; Judge and Bono, 2001).

Robbins and Judge (2006) believe that working ability related to the willingness of individuals to perform some tasks in a job, an intellectual competence to do the mental activity, and physical ability to perform the tasks that require strength and skill. Moreover, LeRouge et al. (2006) state that individual's ability would be optimal to support the environmental work in dealing with the obstacles. Thus, the individual ability can be interpreted as the capability to perform tasks in a particular behavior. Sigh and Greenhaus (2004) state the interaction between personnel, working environment and organization has an effect on job satisfaction

The work perception has a correlation with working environments (Donald et al. 2005). The work perception which is highly dependent on the working environment will improve the job satisfaction dan job performance (Jex and Bliese, 1999; Lancau and Sandura, 2002; Xiao et al. 2014; Hardiyana et al. 2016). It indicates that the improving perception of work will increase the job satisfaction. Job satisfaction is the degree of someone's feelings, both positive and negative feelings. Job satisfaction indicates the nature of basic needs which is based on an assessment of various aspects such as salary, the relationship between the employee and the work itself (Newstroom and Davis, 2002). The high level of job satisfaction can improve productivity because employees with high levels of satisfaction will be motivated to give better performance (Griffin and Moorhead, 2013)

A study by Jex and Bliese based on a survey to 2,273 U.S Army (1999) showed that self-efficacy is highly correlated with job satisfaction. Furthermore, a study by Peng and Mao (2015) showed that person-job fit and self-efficacy is significantly correlated with job satisfaction. Judge et al. (2003) point the employees with higher self-efficacy are more active, work harder when they have to deal with difficult situations and they are easier to pick themselves up when they are failed. There is still little research that investigates the relation of self-efficacy on work perception and job satisfaction. The purpose of this research is to find the gap of selfefficacy on work perception and job satisfaction, especially in government.

Based on the background of the study, the hypotheses of this study are defined as follows:

(H1) High self-efficacy would lead to higher work perception. 
(H2) High self-efficacy would lead to higher employee satisfaction.

(H3) High work perception would lead to higher employee satisfaction.

\section{Research Methods}

The sampling technique was taking a simple random sampling of 117 employees in government agencies in Bandung. The data collection was done by distributing questionnaires directly to the respondents who fit the predetermined sample criteria and observations made directly on the object of research. The sampling of the population was studied by survey method. According to the results of research conducted, there were 117 respondents who filled out questionnaires and all sorts of them are eligible for further processing.

The hypothesis will be tested by using structural equation modeling which is one of the techniques that examine multi variant series dependency relationships between variables. To process the data, this study uses the Smart PLS 3 program which is a statistical program package for structural equation modeling. This study employs questionnaire method of data collection. The questionnaire was distributed directly to 125 respondents but only 117 questionnaires were completed.

The respondents were asked to provide a response by choosing one of the choices. The scoring on each questions item to the problems in this study was done with Likert scale and Likert five-point anchor, ranging from very unimportant to very important. The instrument of self-efficacy was adopted by The General Self Efficacy in Indonesian version (Schwarzer and Jerusalem, 1995; Luszczynska et al. 2005). The instrument of work perception was adopted from Rivai and Sagala (2013) and was used by Hardiyana et al, (2016). The instrument of employees' satisfaction was adopted from The Minnesota Satisfaction Questionary (MNQ) by Weiss et al (1967). It was proven by Martins and Proença (2012).

The Data Analysis technique of this study is Structural Equation Modelling (SEM). The Component-based Partial Least Squares (PLS) was conducted to predict some purposes regarding self-efficacy, work perception and employees satisfaction on government agency in Bandung. Measurement models by Partial Least Squares (PLS) are based on measurement predictions that have the nature of non-parametric through convergent validity, in which the outer loading is greater than 0.5 (Chin, 1988) and the value of the discriminant validity with average variance extracted (AVE) of each construct and reliability with composite reliability and Cronbach alpha (Fornell and Larcker, 1981). The structural models were evaluated using Rsquares for the dependent construct with Goodness of Fit (GoF) by Tenenhaus (2005) to test the predictive $p$-value as well as the relevance and significance of the parameters of structural lines. The counting results show that five indicators have a factor loading lower than 0.5 .

\section{Result and Discussion}

The analysis profile of respondents intended to identify data based on respondents by sex, the last education, and age. In accordance with the results of research conducted, there were 117 respondents who filled out questionnaires and all of them are eligible for further processing. Profile of respondents is shown in Table 1.

Tabel 1: Characteristic of Respondents

\begin{tabular}{lll}
\hline \multicolumn{1}{c}{ Item } & \multicolumn{1}{c}{ Category } & $\%$ \\
\hline Gender & Male & 49 \\
& Female & 51 \\
Age & <35 years old & 40 \\
& $35-50$ years old & 33 \\
\multirow{3}{*}{ Education } & $>50$ years old & 27 \\
& Senior High School & 12 \\
& Diploma/Bachelor/Master & 88 \\
\hline
\end{tabular}

Based on the results of data processing are known as follows:

Tabel 2: Result of average variance extracted (AVE), Cronbachs alpha and composite realibility 
S. Machmud / International Journal of Research in Business and Social Science,

Vol 6 No 6, 2017 ISSN: 2147-4486

\begin{tabular}{|l|c|c|c|}
\hline \multicolumn{1}{|c|}{ Variables } & AVE & Cronbachs alpha & Composite Reliability \\
\hline Satisfaction & 0.560 & 0.926 & 0.938 \\
\hline Self efficacy & 0.603 & 0.889 & 0.913 \\
\hline Work Perception & 0.568 & 0.843 & 0.886 \\
\hline
\end{tabular}

Path Coefficient and Hypothesis Testing are obtained to know the effect of the overall result of the study. The results of the research hypothesis testing are shown in Tables 3.

Tabel 3: The vaule of Path coefficient

\begin{tabular}{|l|c|c|c|c|}
\hline Variables & Original Sample & T Statistics & P Values & Decision \\
\hline Self Efficacy -> Satisfaction & 0.631 & 5.167 & 0.000 & Accepted \\
\hline Self Efficacy -> Work Perception & 0.865 & 15.911 & 0.000 & Accepted \\
\hline Work Perception -> Satisfaction & 0.357 & 2.864 & 0.005 & Accepted \\
\hline
\end{tabular}

While results $R$ squares as shown in the table 4. Overall $R$ square of variables have good structural model based on Tenenhaus GoF.

Tabel 4: The value of $R$ Squares and Tenenhaus GoF

\begin{tabular}{|l|c|c|c|c|}
\hline Variables & Original Sample & T Statistics & P Values & Tenenhaus GoF \\
\hline Work Perception & 0.749 & 27.912 & 0.000 & Large \\
\hline Satisfaction & 0.915 & 8.288 & 0.000 & Large \\
\hline
\end{tabular}

The results of the research model as follows;

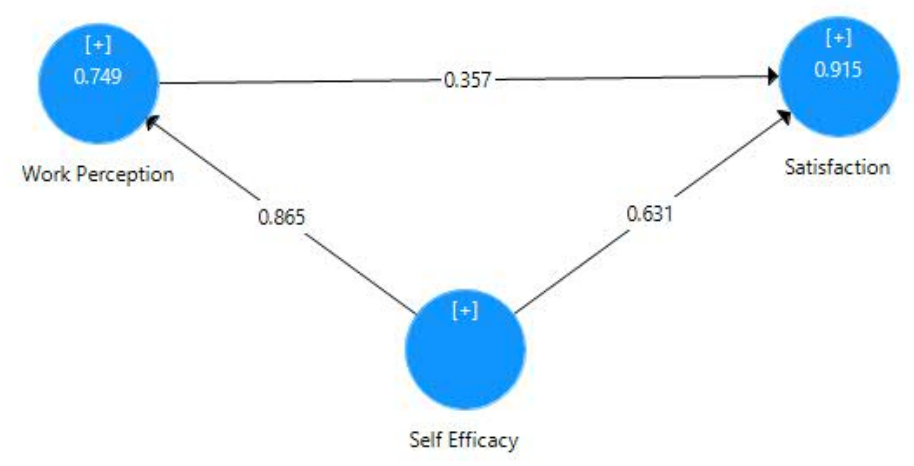

Figure 1. Structural Model of Self Efficacy, Work Perception and Job Satisfaction

Based on the research results can be interpreted that;

(H1) Self Efficacy, Self-efficacy towards job satisfaction have the results of path coefficient 0.631 with $p$ value 0,000 . The result of $p$-value is lower than $5 \%$. Therefore, the self-efficacy significantly influences job satisfaction. The results are consistent with a research by Jex \& Bliese (1999) that proves self-efficacy significantly influences job satisfaction. The results of this study show that the higher self-efficacy will increase job satisfaction. The results are consistent with a research by Millner-Harlee (2010) which stated the working condition has a significant effect on job satisfaction. Furthermore, the research by Peng and Mao (2015) proved that self-efficacy had a significant effect on job satisfaction. 


\section{S. Machmud / International Journal of Research in Business and Social Science,}

Vol 6 No 6, 2017 ISSN: 2147-4486

Employee behavior determines the outcomes, they are in the form of performance, achievement, personal development, relationships with others, and job satisfaction. The behavior can generate the positive longterm achievement and personal growth or vice versa, the long-term poor achievement or less developed achievement (Griffin and Moorhead, 2013). Every individual who works in an organization naturally expects to obtain the useful and profitable aspects for himself. In this case, the behavior and the results serve as feedbacks for the individual and the environment. (Judge and Bono, 1999)

$(\mathrm{H} 2)$ Self Efficacy, the Self-efficacy towards work perception has the results of path coefficient 0.865 with $p$ value 0,000 . The result of $p$-value is lower than $5 \%$. Therefore, the self-efficacy significantly influences the work perception. These results are consistent with the concept of social cognitive theory which states that self-efficacy will establish someone's confidence to complete their job (Peng et al. 2013). Self-efficacy plays an important role in an individual self-confidence on the job. It enables the employee to overcome challenges and obstacles. In accordance with Judge et al (2003), the higher the self-efficacy of the employees, the more they have confidence in their abilities to perform different and unanticipated tasks in uncertain situations. If the workers believe in their ability, they will be bound to the behaviors that play a role in improving the quality of work. A person with higher self-efficacy will be confident to overcome an obstacle in working environment, work relationship, work overload, job-security, control and stressors (Donald et al. 2005).

(H3) Work Perception, the Work perception towards job has the results of path coefficient 0.357 with p-value 0,005 . The result of $p$-value is lower than $5 \%$. Therefore, the work perception significantly influences job satisfaction. The results support the research by Faye \& Long (2014) which proves that the work-related outcomes in the public sector proved to have a significant effect on job satisfaction. The results are in accordance with a research conducted by Millner-Harlee (2010) which shows that the working condition has a significant effect on job satisfaction. An evidence that shows work perception is strongly associated with job satisfaction can be found in a study by Fu \& Deshpande(2014) who investigated the behavior of employees and job satisfaction of insurance companies in China.

The employees who are motivated to work are the employees who saw their work to help achieve the goal. In the other words, the creation of a harmonious relationship between employees with the organization is important. Therefore, it can form a positive or negative perception of the organization. When one of the characteristics of the organization perceived by employees as a positive condition or giving a job satisfaction, it will improve the ability to achieve the organizational goals. This idea is in accordance with Al-Tit and Suifan (2015) who proved that there is a significant influence on perceptions about the work of the employee's behavior, which in turn increases the employees' satisfaction. Inversely, when the employees perceive that one of the characteristics of the work environment does not match the expectations and the individual needs, it leads to job dissatisfaction feelings. Another study by Najafi et al. (2011) also proved that employees' attitudes directly influence the job satisfaction.

The employees' job satisfaction or dissatisfaction will determine whether the goal is achieved by the organizational settings or not. As previously stated, the satisfaction or dissatisfaction is closely related to the work activities and the productivity of the company. The employees who are satisfied with the job is likely to be more enthusiasm in their work. In addition, they are able to meet the employment targets. However, it would be different when an employee is not satisfied with the working conditions. This condition will hamper his or her work activities. In the other words, dissatisfaction is the starting point of the problems that arise in an organization, for instance, the conflict, absenteeism, turnover, as well as many other problems that can affect the process of achieving organizational goals (Griffin and Moorhead, 2013). From the workers' side, employee dissatisfaction will decrease the motivation to work, work morale, loyalty to the organization and ultimately lead to decrease the performance, both qualitatively and quantitatively. This statement is in accordance with a study by McNeese-Smith (1996) which states that an employee's behavior significantly influences the employee's satisfaction. Moreover, it is in line with a research conducted by Falkenburg \& Schyns (2007). It proved that job satisfaction is influenced by the attitude of employees. Their perception of the condition of the work environment will arise the satisfaction or dissatisfaction feeling; it will still affect their work behavior. 


\section{S. Machmud / International Journal of Research in Business and Social Science,}

Vol 6 No 6, 2017 ISSN: 2147-4486

The results of this study indicate that the perception of work and job satisfaction show that R- squares 0.749 and 0.915 . These results reveal the structural model of self-efficacy on work perception and job satisfaction are good criteria.

\section{Conclusion}

This study contributes to the development of social cognitive theory in which the self-efficacy plays an important role on work perception and job satisfaction. The study shows that self-efficacy significantly influences the work perception and job satisfaction. The work perception is proven to be a significant effect on job satisfaction. It shows that the high level of self-efficacy can increase the work perception and job satisfaction. Moreover, this study indicates that the adequate levels of self-efficacy will be a positive influence on the behavior of employees in their duties. The contentment in carrying out the task at hand will lead to satisfaction in their work. When the employees work efficiently and effectively, it will increase their productivity.

This study still has some limitations in the effect of self-efficacy perception and employees satisfaction on work. It needs further study to include some variables that are expected to influence the perception and employees satisfaction such as gender factors, demographics, reward and punishment, facilities and infrastructure to produce a more comprehensive result.

\section{References}

Al-Tit, A. A., and Suifan, T. S. (2015). The Mediating Role of Job Characteristics in the Relationship between Organizational Commitment and Job Satisfaction. International Journal of Business and Management, 10(9): 215-222. http://dx.doi.org/10.5539/ijbm.v10n9p215.

Barney, J, B., Wright, M., and Ketchen, Jr, D, J,. (2001). The resource-base view of the firm: ten years after 1991. Journal of Management, 27: 625-641.

Baum, R., and Locke, E. A. (2004). The relationship of entrepreneurial traits, skill and motivation to subsequent venture growth. Journal of Applied Psychology, 89(4): 587-598.

Becker, G. S. (1964). Human capital: A theoretical and empirical analysis, with special reference to education. New York: National Bureau of Economic Research.

Chandler, G. N. (2008). Organizational learning and new venture performance. Proceedings, USASBE, 0240-0255.

Chin, W. W. (1998), The Partial Least Squares Approach for Structural Equation Modelling. In Marcoulides, G. A. (Ed). Modern Method for Business Research. Mahwah. NJ. Erlbaum.

Donald, I., Taylor, P., Johnson, S., Cooper, C., Cartwright, S., and Robertson, S. (2005). Work environments, stress, and productivity: An examination using ASSET. International Journal of Stress Management, 12(4): 409-423.

Edwards, J. R., and Cooper, C. L. (1990). The person-environment fit approach to stress: recurring problems and some suggested solutions. Journal of organizational behavior, 11(4): 293-307.

Falkenburg, K., and Schyns, B. (2007). Work satisfaction, organizational commitment and withdrawal behaviours. Management Research News, 30(10): 708-723. DOI 10.1108/01409170710823430.

Faye, K., and Long, Y. (2014). The Impact of Job Satisfaction in the Relationships between Workplace Politics and Work Related Outcomes and Attitudes: Evidence from Organizations in Senegal. International Journal of Business and Management, 9(5): 160-168. doi:10.5539/ijbm.v9n5p160.

Fornell, C., and Larcker, D. (1981). Evaluating Structural Equation Models with Unobservable Variable and Measurement Error. Journal of Marketing Research, 18: 39-50. 
Fu, W., and Deshpande, S. P. (2013). The Impact of Caring Climate, Job Satisfaction, and Organizational Commitment on Job Performance of Employees in a China's Insurance Company. J Bus Ethics, 124:339-349. DOI 10.1007/s10551-013-1876-y.

Gibson, J.L., Ivancevich, J.M., Donnelly, J.H., and Konopaske, R. (2006). Organizations: Behavior, Structure, Processes. 12th edition. Boston: McGraw-Hill Irwin.

Griffin, R. W., and Moorhead, G. (2013). Perilaku Organisasi: Manajemen Sumberdaya Manusia, Jakarta: Penerbit Salemba Empat.

Hardiyana, A., Yusup, M., and Sidharta, I. (2016). Perception of Work and Organization Commitment toward Employee Satisfaction on Non-Ministerial Government Agencies in Bandung Indonesia. Journal of Knowledge Management, Economics and Information Technology, 6(1):1-15.

Hmieleski, K, M., and Baron, R. A. (2008). When does entrepreneurial self efficacy enhance versus reduce firm performance?. Strategic Entrepreneurship Journal, 2(1): 57-72.

Jarvenpaa, S, L., and Leidner, D. E. (1998). An informational company in Mexico: extending the resource base view of the firm to developing country context. Information System Research, 9(4): 342-361.

Jex, S. M., and Bliese, P. D. (1999). Efficacy beliefs as a moderator of the impact of work-related stressors: a multilevel study. Journal of applied psychology, 84(3): 349-361.

Judge, T. A., and Bono, J. E. (2001). Relationship of core self-evaluations traits-self-esteem, generalized self-efficacy, locus of control, and emotional stability-with job satisfaction and job performance: A meta-analysis. Journal of applied Psychology, 86(1): 80-92.

Judge, T. A., Erez, A., Bono, J. E., and Thoresen, C. J. (2003). The core self-evaluations scale: Development of a measure. Personnel psychology, 56(2): 303-331.

Judge, T. A., Thoresen, C. J., Bono, J. E., and Patton, G. K. (2001). The job satisfaction-job performance relationship: A qualitative and quantitative review.Psychological bulletin, 127(3): 376-407.

Lankau, M. J., and Scandura, T. A. (2002). An investigation of personal learning in mentoring relationships: Content, antecedents, and consequences. Academy of Management Journal, 45(4): 779-790.

LeRouge, C., Nelson, A., and Blanton, J. E. (2006). The impact of role stress fit and self-esteem on the job attitudes of IT professionals. Information \& Management, 43(8): 928-938.

Luszczynska, A., Gutiérrez-Doña, B., and Schwarzer, R. (2005). General self-efficacy in various domains of human functioning: Evidence from five countries. International Journal of Psychology, 40(2): 80-89.

Luthans, F. (2006). Perilaku Organisasi, Edisi 10, Yogyakarta: Penerbit Andi.

Machmud, S., and Sidharta, I. (2016). Entrepreneurial Motivation and Business Performance of SMEs in the SUCI Clothing Center, Bandung, Indonesia. DLSU Business \& Economics Review, 25(2): 63-78.

Millner-Harlee, T. (2010). A Multiple Case Study Discovering Part-Time Faculties' Perceptions of Their Professional Needs, Working Conditions, Social Network, and Job Satisfaction at Three Community Colleges. Dissertation. George Washington University.

Najafi, S., Noruzy, A., Azar, H. K., Nazari-Shirkouhi, S., and Dalvand, M. R. (2011). Investigating the relationship between organizational justice, psychological empowerment, job satisfaction, organizational commitment and organizational citizenship behavior: An empirical model. African Journal of Business Management, 5(13): 5241-5248, DOI: 10.5897/AJBM10.1505.

Newbert, S. L. (2007). Empirical research on the resource base view of the firm: an assessment and suggestions for future research. Strategic Management Journal, 28(2): 121-146.

Newstrom, J. W., \& Davis, K. (2002). Organizational behavior (1 Ith ed.). New York: McGrawHill Higher Education. 
Peng, Y., and Mao, C. (2015). The impact of person-job fit on job satisfaction: the mediator role of Self efficacy. Social Indicators Research, 121(3): 805-813.

Peng, J., Miao, D., and Xiao, W. (2013). Why are gainers more risk seeking.Judgment and Decision Making, 8(2): 150-160.

Rivai, V., and Sagala, E. J. (2013). Manajemen Sumber Daya Manusia dari Teori ke Praktek, Jakarta: Penerbit PT Rajagrafindo Persada.

Robbins, S. P., and Judge, T. A. (2006). Perilaku Organisasi (Organizaztional Behavior) buku 1. Jakarta: Salemba Empat.

Schultz, T. (1961). Investment in human capital. The American Economic Review, 51(1): 1-17.

Schwarzer, R., and Jerusalem, M. (1995). Generalized Self-Efficacy scale. In J. Weinman, S. Wright, \& M. Johnston, Measures in health psychology: A user's portfolio. Causal and control beliefs (pp. 35-37). Windsor, England: NFER-NELSON.

Sidharta, I., and Affandi, A. (2016). The Empirical Study on Intellectual Capital Approach toward Financial Performance on Rural Banking Sectors in Indonesia. International Journal of Economics and Financial Issues, 6(3): 1247-1253.

Tenenhaus, M., Vinzi, V. E., Chatelin, Y. M., and Lauro, C. (2005), PLS path modeling. Computational statistics \& data analysis, 48(1): 159-205.

Wagner, H. T. (2006). Managing the impact of IT on firm success: the link between the resource base view and the IT infrastructure library. IEEE-proceedings of the 39 Hawaii International Conference on System Science, 1-10.

Weiss, D. J., Dawis, R. V., and England, G. W. (1967). Manual for the Minnesota Satisfaction Questionnaire. Minnesota Studies in Vocational Rehabilitation, 22: 120.

Wernerfelt, B. (1984). A resource base view of the firm. Strategic Management Journal, 1(2): 171-180.

Wood, R. E., \& Bandura, A. (1989). Social cognitive theory of organizational management. The Academy of Management Reviews, 14(3): 361-384.

Xiao, W., Zhou, L., Wu, Q., Zhang, Y., Miao, D., Zhang, J., \& Peng, J. (2014). Effects of person-vocation fit and core self-evaluation on career commitment of medical university students: the mediator roles of anxiety and career satisfaction. International journal of mental health systems, 8(8): 1-6. DOI: 10.1186/1752-4458-8-8 